\title{
PROCES TWORZENIA OFERTY EDUKACYJNEJ W BIBLIOTECE AKADEMICKIEJ - NA PRZYKŁADZIE BIBLIOTEKI UNIWERSYTECKIEJ W WARSZAWIE
}

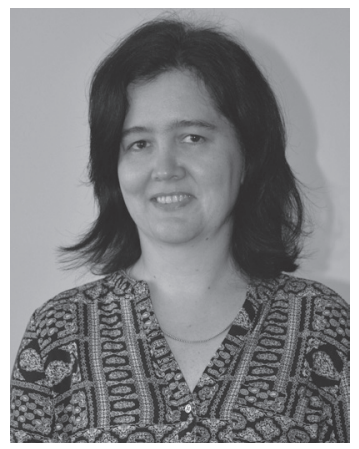

Lilianna Nalewajska od 2007 r. pracuje w Bibliotece Uniwersyteckiej w Warszawie w Oddziale Usług Informacyjnych i Szkoleń. Zajmuje się działalnością informacyjną i dydaktyczną, prowadzi badania użytkowników, w tym zagranicznych, oraz dotyczące edukacji informacyjnej. Publikowała m.in. w „Przeglądzie Bibliotecznym”, „Bibliotekarzu” oraz w „Poradniku Bibliotekarza". Prowadzi również badania z zakresu kostiumologii.

SŁOWA KLUCZOWE: Edukacja informacyjna. Pedagogika biblioteczna. Biblioteka akademicka. Szkolenia biblioteczne. Potrzeby informacyjne. Użytkownicy informacji. Zachowania informacyjne. Biblioteka Uniwersytecka w Warszawie.

ABSTRAKT: Teza/cel artykułu - Celem artykułu jest zaprezentowanie procesu tworzenia oferty edukacyjnej w bibliotece akademickiej. Opis elementów tego procesu, zastosowanych badań diagnostycznych, ich rezultatów oraz sposobów ich wykorzystania do stworzenia oferty edukacyjnej mogą posłużyć innym bibliotekom uczelnianym jako pomoc przy planowaniu oraz późniejszym monitorowaniu i promowaniu zajęć edukacyjnych. Metody badań - Opis etapów kilkuletniego procesu budowania oferty szkoleniowej; analiza stosowanych rozwiązań metodologicznych (formy szkoleń) z lat 2012-2017. Analizie poddano mocne i słabe strony powstałej oferty. W przypadku badania opinii użytkowników jako sposób postępowania badawczego wybrano metodę sondażu diagnostycznego, 
a jako metodę badawczą zastosowano ankietę. Wyniki - Proces tworzenia oferty edukacyjnej należy poprzedzać szerokim rozpoznaniem dotyczącym oferty szkoleniowej w systemie bibliotecznym uczelni. Niezbędne jest poznanie opinii odbiorców oferty szkoleniowej - studenci wykazali duże zainteresowanie korzystaniem ze szkoleń, z preferencją do dobrowolnego w nich uczestniczenia. Rezultaty badań diagnostycznych wskazały dwie równorzędnie preferowane formy szkoleń: prowadzone na miejscu w bibliotece, z możliwością interakcji z prowadzącym, oraz szkolenia online w formie krótkich tutoriali lub filmów. Wnioski - Tworzenie oferty edukacyjnej bibliotek uczelnianych należy poprzedzać badaniami diagnostycznymi potrzeb i umiejętności informacyjnych użytkowników w celu stworzenia oferty jak najpełniej odpowiadającej oczekiwaniom uczestników. Jest to proces długotrwały, ulegający fluktuacjom związanym z odbiorem oferty. Nieodzowne jest także promowanie szkoleń na uczelni wśród zróżnicowanych kręgów odbiorców (studenci, doktoranci, pracownicy naukowi).

\section{WPROWADZENIE}

W Polsce edukacja informacyjna (ang. information literacy) (Edukacja informacyjna, 2017) rozwija się niezwykle powoli, pomimo ponad 40 lat intensywnych prac w tym zakresie prowadzonych na całym świecie ${ }^{1}$. Dziś, podobnie, jak i wcześniej, ludzie na różnych poziomach swojego życia prywatnego i zawodowego borykają się z trudnościami w dotarciu do informacji, korzystaniu ze źródeł, oceną ich jakości i przydatności. Edukacja informacyjna jest w naszym kraju nadal słabo reprezentowana, nawet na poziomie edukacji wyższej. Do tej sytuacji przyczynia się w dużej mierze brak uregulowań prawnych oraz dyskusji na ten temat w środowisku naukowym, a także niewystarczające działania w kręgach bibliotekarskich, jak również brak ukierunkowanych prac nad jej założeniami i ogólnokrajowymi czy choćby instytucjonalnymi (uczelnianymi) standardami.

W literaturze krajowej z zakresu edukacji informacyjnej ${ }^{2}$ poruszane są zazwyczaj zagadnienia teoretyczne dotyczące problematyki nauczania dorosłych, szkoleń z zakresu edukacji informacyjnej, czy kompetencji młodzieży. Sporadycznie publikowane są wyniki badań ewaluacyjnych po przeprowadzonych już szkoleniach (Jerzyk-Wojtecka, 2015). Nadal publikuje się jednak zbyt mało przykładów i analiz konkretnych doświadczeń, czy opisów zastosowanych rozwiązań ${ }^{3}$ W tym kontekście niniejszy

\footnotetext{
1 Terminu ,,information literacy” po raz pierwszy użył Paul Zurkovski w 1974 r. (Badke, 2010).

2 Zagadnieniu edukacji informacyjnej (information literacy) w ujęciu praktycznym i teoretycznym zostały poświęcone m.in.: „Bibliotheca Nostra” nr 1 i 2, 2012 r., w nr 1, 2013 r. zawarto wieloaspektowe omówienie wspomnianego zagadnienia wraz z zestawieniem obszernego piśmiennictwa polskiego i zagranicznego oraz raportem na temat stanu edukacji informacyjnej w polskich bibliotekach akademickich (Dziak \& Rozkosz, 2013); teksty w „Biuletynie EBIB” (nr 1, 2005 r., nr 4, 2009 r., nr 2, 2011 r.).

3 Jako wyjątkowa w tym kontekście jawi się pozycja: MedLibTrain: zostań lepszym nauczycielem kompetencji informacyjnych: przewodnik nie tylko dla bibliotekarzy medycznych (MedLibTrain 2010) oraz cykl artykułów opartych na wynikach badań ankietowych przeprowadzonych wśród studentów medycyny z Wydziału Lekarskiego UJ CM w Krakowie nt. roli szkoleń w nabywaniu umiejętności infor-
} 
artykuł stanowi wkład do zasobu empirycznych obserwacji na temat edukacyjnej roli bibliotek akademickich w Polsce, ponieważ jego celem jest zaprezentowanie procesu tworzenia oferty edukacyjnej w Bibliotece Uniwersyteckiej w Warszawie (BUW). Przedstawione działania i doświadczenia Oddziału Usług Informacyjnych i Szkoleń (OUiS), wcześniej Oddziału Udostępniania i Informacji Naukowej (OUIN) ${ }^{4}$ w BUW przy budowaniu oferty dydaktycznej z lat 2012-2017 mogą posłużyć jako baza porównawcza dla działań o zbliżonym zakresie podejmowanych przez inne ośrodki.

Pomimo faktu, że biblioteki przestały pełnić rolę głównego dostawcy informacji, przynajmniej w opinii młodych ludzi, którzy wyszukiwanie informacji rozpoczynają od zasobów dostępnych w otwartym Internecie, a często także do nich ograniczają, właśnie te instytucje powinny kształtować głębszą świadomość korzystania z różnego typu źródeł i narzędzi informacyjnych. Coraz częściej przywoływana i realizowana jest koncepcja biblioteki uczącej (ang. teaching library) (Sühl-Strohmenger, 2012). Edukacja informacyjna prowadzona przez biblioteki akademickie, powinna zatem w coraz szerszym zakresie wykraczać poza podstawowe, wstępne szkolenia biblioteczne, zapoznające jedynie ze zbiorami oraz zasadami korzystania z nich w bibliotece i skierowane wyłącznie do studentów rozpoczynających studia. Rozwój świadomości informacyjnej leży bowiem u podstaw umiejętnego wyszukiwania i oceny zdobytych informacji oraz korzystania $\mathrm{z}$ dostępnych danych w celu budowania własnej wiedzy oraz prowadzenia badań naukowych podczas całego toku edukacji na poziomie wyższym, jak i w późniejszym życiu zawodowym oraz prywatnym (uczenie się przez całe życie). W kontekście edukacji informacyjnej coraz silniej podnoszone jest znaczenie kształcenia umiejętności krytycznego myślenia, co znalazło odzwierciedlenie w najnowszej definicji information literacy (CILIP, 2018).

Biblioteki akademickie, jako centra nauki czy laboratoria informacyjne, starają się wspomagać kształcenie umiejętności informacyjnych użytkowników. W polskich bibliotekach uczelnianych najczęściej realizowane są szkolenia z zakresu korzystania ze zbiorów i źródeł informacji oferowanych przez biblioteki (katalogi) oraz uczelnie (licencjonowane zasoby elektroniczne), jak również tych dostępnych w sieci Internet, uczą korzystania z narzędzi wyszukiwawczych oraz narzędzi do tworzenia i zarządzania bibliografia, przybliżają zasady etycznego wykorzystania zebranych informacji - uczą przepisów prawa chroniącego własność intelektualną. Na tle działań podejmowanych przez biblioteki zagraniczne, głównie z kręgu anglosaskiego i amerykańskiego, tamtejszych doświadczeń oraz stosowa-

\footnotetext{
macyjnych, ich wpływu na zmianę samooceny w zakresie kompetencji informacyjnych uczestników opublikowany w nr 1 „Forum Bibliotek Medycznych” 2011 r.

${ }^{4}$ W 2013 r. przeprowadzona została zmiana struktury BUW, od tego czasu funkcjonuje Oddział Usług Informacyjnych i Szkoleń (OUiS).
} 
nych rozwiązań, ujawniają się istotne różnice w sposobach realizowania postulatów edukacji informacyjnej. Dotyczą one m.in. takich kwestii jak: osadzenie szkoleń bibliotecznych w kontekście edukacyjnym, włączanie ich do systemu akredytacji, współpraca bibliotekarzy i kadry naukowej przy tworzeniu oferty dydaktycznej oraz ocenie efektów edukacji, czy prowadzenie długofalowych badań dotyczących wyboru i efektywności stosowanych metod dydaktycznych (pre- i post-testy) (Mery, et al., 2012; Hoffman \& LaBonte, 2012; Anderson \& May, 2010). Podstawę działań stanowią tam często standardy kompetencji informacyjnych wypracowane przez organizacje edukacyjne lub bibliotekarskie ${ }^{5}$, uznawane na tamtejszych uczelniach.

W związku ze zmieniającym się środowiskiem informacyjnym, wzrastającym udziałem mediów społecznościowych i nowych technologii, współpraca online także w środowiskach naukowych, problematyka podnoszenia umiejętności informacyjnych rozpatrywana jest w coraz szerszym spektrum. Jak piszą Mackey i Jacobson redefinicja edukacji informacyjnej rozszerza zakres ogólnie rozumianych kompetencji informacyjnych i kładzie szczególny nacisk na tworzenie i dzielenie się zasobami informacyjnymi w cyfrowym środowisku uczestniczącym (Mackey \& Jacobson, 2011, s. 62). Metaliteracy, czyli wieloaspektowe kształcenie wielu kompetencji: informacyjnych i cyfrowych, zdolności krytycznego oceniania dynamicznej zawartości Internetu przy jednoczesnym partycypacyjnym korzystaniu z sieci (Mackey \& Jacobson, 2011, p. 66) wyznacza kierunek przyszłych działań edukacyjnych prowadzonych w bibliotekach akademickich.

Rozbudowa oferty szkoleniowej staje się zatem wartością dodaną zarówno dla użytkowników bibliotek, jak i dla funkcjonowania samej książnicy oraz uczelni. Podnoszone w literaturze zagranicznej obserwacje dotyczące spadku liczby użytkowników bibliotek, w tym również bibliotek akademickich, zachodzące $\mathrm{w}$ związku $\mathrm{z}$ wszechobecnością źródeł oraz usług dostępnych online, spowodowały, że zaczęto badać przełożenie relacji oferty edukacyjnej na wzrost lub przynajmniej utrzymanie liczby studentów korzystających z zasobów oraz usług bibliotek (Portmann \& Roush, 2004; Walsh, 2008). Ma to oczywiście wpływ także na kwestie ekonomiczne - finansowanie bibliotek i ich działalności w zależności od stopnia ich wykorzystywania.

Na tle zmian zachodzących we współczesnej dydaktyce bibliotecznej, poszerzaniu jej rozumienia oraz włączaniu w jej krąg nowych aspektów (Secker \& Coonan, 2013) należy zastanowić się nad stanem edukacji informacyjnej $\mathrm{w}$ bibliotekach polskich uczelni, przeanalizować kierunki możliwych zmian i dążeń, ale także ograniczenia w ich realizacji. Zada-

\footnotetext{
${ }^{5}$ M.in. amerykańskie „The Association of College and Research Libraries Information Literacy Competency Standards for Higher Education” (ACRL, 2015), brytyjskie „Seven Pillars” przygotowane przez the Society of College, National and University Libraries (SCONUL, 2011).
} 
niem niniejszego tekstu jest pokazanie, jak złożony i długotrwały może okazać się proces tworzenia przez bibliotekę akademicką oferty dydaktycznej w sposób odpowiadający potrzebom użytkowników oraz realizujący, choćby w części, postulaty edukacji informacyjnej na poziomie szkolnictwa wyższego. Podejmowane działania i ich rezultaty, potrzeby oraz możliwe rozwiązania opisano zgodnie $\mathrm{z}$ etapami procesu prowadzonego w BUW na przestrzeni kilku lat. Omówiono następujące etapy:

- analiza oferty szkoleniowej BUW przed rokiem akademickim 2013/2014;

- analiza oferty edukacyjnej bibliotek wydziałowych Uniwersytetu Warszawskiego z 2013 r.;

- I badanie diagnostyczne użytkowników w roku akademickim 2012/2013;

- nowa oferta szkoleniowa z roku 2014;

- II badanie diagnostyczne użytkowników w roku akademickim 2015/2016;

- kurs „Napisz z nami tekst naukowy”;

- podsumowanie - wnioski i propozycje rozwiązań.

\section{OPIS ETAPÓW PROCESU}

ANALIZA OFERTY SZKOLENIOWEJ BUW PRZED ROKIEM AKADEMICKIM 2013/1014

W 2013 r. dążeniem ówczesnego Oddziału Udostępniania i Informacji Naukowej BUW było poszerzenie oferty edukacyjnej tak, by wykraczała ona poza wstępne szkolenie dla studentów I roku studiów licencjackich. Założeniem było wypracowanie oferty szkoleń doskonalących efektywne korzystanie z zasobów BUW (kompetencje biblioteczne), jak również kształtujących pogłębioną świadomość korzystania z informacji dostępnych $w$ sieci Internet, specjalistycznych, dziedzinowych, dotyczących elektronicznych źródeł informacji oraz korzystania z narzędzi wyszukiwawczych. Szkolenia kierowano głównie do studentów II oraz III stopnia, ale również do innych zainteresowanych użytkowników ze względu na fakt, że BUW ustawowo pełni funkcję biblioteki publicznej. Jedną z przyczyn tak szeroko zakrojonego planowania była również tendencja spadkowa liczby studentów szkolonych w BUW. Zmniejszała się także liczba jednostek UW zgłaszających grupy studentów na szkolenia w BUW (w 2009 r. - 16 jednostek; 2010 r. - 14; 2011 i 2012 r. - po 13). Jednocześnie spadała liczba studentów I roku szkolących się online (w 2008 r. - 5923 osoby; 2009 r. $-5867 ; 2010$ r. - 4812; 2011 r. - 4544; 2012 r. - 3532) $)^{6}$. Innym

\footnotetext{
${ }^{6}$ Dane na podstawie rocznych sprawozdań BUW (Sprawozdanie BUW 2009, s. 81; Sprawozdanie BUW 2010, s. 80; Sprawozdanie BUW 2011, s. 74-75; Sprawozdanie BUW 2012, s. 73). Należy dodać, że w latach 2009-2012 liczba studentów przyjętych na studia I stopnia oraz jednolite magisterskie na UW z reguły systematycznie wzrastała (wyniki rekrutacji z lat od 2007/2008 do 2009/2010 dostępne w:
} 
istotnym powodem było dążenie do wypracowania zróżnicowanej oferty edukacyjnej wpisującej się w założenia edukacji informacyjnej i kształcenia na wielu etapach życia.

Budowanie skutecznego programu edukacyjnego powinno opierać się na danych empirycznych, potwierdzających rzeczywiste potrzeby i już posiadane kompetencje uczestników szkoleń (nabyte m.in. na poziomie edukacji szkolnej). Dane dotyczące stanu wyjściowego, zebrane np. podczas badań diagnostycznych, powinny stanowić podstawę rozważań przy budowaniu oferty edukacyjnej (pre-testy). W literaturze przedmiotu podnoszona jest także kwestia efektywności szkoleń (Dziak, 2013; Samson, 2010; Oakleaf, 2008; Oakleaf \& Kasla, 2009) osiąganej dzięki koncentracji działań właśnie na potrzebach odbiorców (ang. learner-centered approach) (Maybee, 2006; Andretta, 2011; Bond, 2016). Planując zmiany w systemie szkoleniowym w BUW, dokonano więc analizy wcześniejszego stanu. Biblioteka Uniwersytecka w Warszawie od kilku lat oferowała dwie podstawowe formy szkolenia bibliotecznego (dawniej nazywanego przysposobieniem) dla studentów rozpoczynających studia: prowadzone na miejscu oraz online ${ }^{7}$, które przybliżały podstawowe zasady korzystania z zasobów oraz usług BUW. W 2009 r. podjęto decyzję o stopniowym rozszerzaniu oferty szkoleniowej w wersji online ( $w$ formie prezentacji PowerPoint) - rozpoczęto przygotowywanie szkoleń dziedzinowych obejmujących tematy z zakresu wyszukiwania informacji, tworzenia i korzystania z bibliografii oraz dziedzinowe do działów: Muzyka, Nauki ścisłe oraz części wstępnej, wspólnej dla wszystkich prezentacji (Sprawozdanie OUIN, 2009, s. 16). W kolejnym roku pracowano nad materiałem $\mathrm{z}$ dziedziny Język. Literatura $^{8}$. Wstępna część prezentacji nie została jednak zaaprobowana przez wicedyrektor BUW nadzorującą cały proces, dlatego w roku następnym kontynuowano prace nad tworzeniem zarówno zawartości merytorycznej, jak i szablonów prezentacji (Sprawozdanie OUIN, 2010, s. 17). Od 2010 r. kontynuowano szkolenia dotyczące korzystania z czasopism i książek elektronicznych - były to zarówno szkolenia ogólne, dotyczące podstawowych sposobów wyszukiwania w bazach, jak i profilowane, skierowane do osób zainteresowanych lub na zamówienia jednostek UW (Sprawozdanie BUW, 2010, s. 81). W 2011 r. bibliotekarz dziedzinowy z zakresu prawa jednorazowo przeprowadził webinarium poświęcone sztuce

\footnotetext{
Sprawozdanie roczne Rektora UW za rok 2009 (2010), s. 18; zestawienie za lata 2011/2012 - 2012/2013 w: Sprawozdanie Rektora UW z działalności uczelni w 2012 r. (2013), s. 26).

${ }^{7}$ W BUW szkolenie biblioteczne online udostępnione zostało w $2003 \mathrm{r}$. na platformie Moodle, w tej formie, z aktualizowanymi treściami, funkcjonuje do chwili obecnej. Taką formę szkolenia dla swoich studentów wybiera zdecydowana większość jednostek UW.

${ }^{8}$ Księgozbiór w wolnym dostępie w BUW zorganizowany jest wg Klasyfikacji Biblioteki Kongresu $\mathrm{w}$ Waszyngtonie; ustawiony jest $\mathrm{w}$ podziale na osiem szerokich dziedzin: Język. Literatura; Filozofia. Psychologia. Religia. Oświata; Nauki historyczne; Geografia. Nauki matematyczne, przyrodnicze, stosowane; Muzyka. Architektura. Sztuki piękne; Prawo. Nauki polityczne; Nauki społeczne. Antropologia; Dzieła treści ogólnej. Bibliotekoznawstwo.
} 
korzystania ze zbiorów prawniczych BUW. Opracowano również prezentacje do planowanych w wersji online szkoleń z zakresu: architektura, pedagogika, medycyna (Sprawozdanie OUIN, 2011, s. 20). W kolejnym roku przygotowane zostały materiały z dziedzin: Prawo. Nauki polityczne oraz Nauki społeczne. Antropologia. Powstała ponadto prezentacja dotycząca podstaw korzystania z narzędzia RefWorks, która miała stać się punktem wyjścia do szkoleń z tego zakresu prowadzonych od 2013 r., zarówno na miejscu w BUW, jak i w formie webinariów (Sprawozdanie OUIN, 2012, s. 22). Przygotowano także projekt ankiety ewaluacyjnej dla uczestników szkoleń9.

W styczniu 2011 r. została powołana Komisja ds. Edukacji Informacyjnej SBP, której misją było wprowadzanie alfabetyzacji informacyjnej do polskiego środowiska bibliotecznego oraz podejmowanie inicjatyw służących jej promocji i popularyzacji we wszystkich typach bibliotek. Komisja była jednym z organizatorów warsztatów dla trenerów information litera$c y$, które odbyły się w BUW. Po ich zakończeniu przeanalizowano ofertę dydaktyczną BUW oraz rozwiązania możliwe do zastosowania w przyszłości. Podjęto następujące działania:

- przeprowadzono analizę SWOT w zakresie możliwości dydaktycznych Sekcji Informacji i Dydaktyki OUIN BUW;

- pracownicy Sekcji Informacji i Dydaktyki OUIN uczestniczyli w konferencji „Jak uczyć skutecznie?", zorganizowanej w ramach Programu doskonalenia nauczycieli akademickich UW projektu „Nowoczesny Uniwersytet” oraz prezentacji pt.: „Badania zachowań informacyjnych pracowników Wydziału Historycznego UW" opracowanej przez pracownika Instytutu Informacji Naukowej i Studiów Bibliotecznych UW;

- przeprowadzono wstępną ankietę wśród bibliotek wydziałowych UW nt. oferty szkoleniowej bibliotek UW.

Nie udało się nawiązać ściślejszej współpracy z jednostkami dydaktycznymi UW oraz opiekunami pierwszych lat studiów. Jednak w roku następnym zainicjowano wizyty bibliotekarzy dziedzinowych BUW w bibliotekach wydziałowych UW w celu nawiązywania ściślejszej współpracy. W tym też roku, aby lepiej poznać specyfikę wymagań edukacyjnych w bibliotece akademickiej oraz kwestie związane z edukacją informacyjną pracownicy Sekcji Informacji i Dydaktyki OUIN mieli możliwość spotkać się z dr Wendy Holliday z Utah State University ${ }^{10} \mathrm{i}$ uczestniczyć w szkoleniu pt.: The Teaching Librarian: Understanding Information Literacy as a Personal and Institutional Practice. Wykład wprowadzający w tematykę

9 Ankieta została wdrożona, zbiera ogólne opinie uczestników na temat szkoleń oraz prowadzących je osób; jest poddawana bieżącej analizie przez każdego z bibliotekarzy.

${ }^{10}$ Dr Wendy Holliday obecnie pracuje w Cline Library (Northern Arizona University), gdzie kieruje działem Academic Programs and Course Support. W latach 2004-2013 była koordynatorem ds. szkoleń bibliotecznych w Utah State University. Od wielu lat zajmuje się tematyką edukacji informacyjnej, jest aktywną członkinią ACRL (https://works.bepress.com/wendy_holliday/). 
edukacji informacyjnej i zaprezentowanie metod pracy dydaktycznej stosowanych przez praktykującą bibliotekarkę z uczelni amerykańskiej były ważnym doświadczeniem dla bibliotekarzy dziedzinowych BUW. Prowadząca podkreślała wówczas, że efektywność szkoleń bibliotecznych zależy od stopnia powiązania ich z konkretnymi potrzebami uczestników.

W 2013 r. uruchomiono szkolenia dziedzinowe prowadzone na miejscu w BUW. Były to dwa cykle: dotyczący elektronicznych baz prawniczych oraz RefWorks. Niestety, zainteresowanie nimi okazało się niewielkie, mimo promowania ich na stronie internetowej BUW i rozsyłania informacji do bibliotek wydziałowych UW.

Bardzo pomocne w trakcie rozważań nad możliwościami rozbudowy oferty szkoleniowej okazały się doświadczenia bibliotekarzy uczestniczących w zagranicznych wyjazdach szkoleniowych $\mathrm{w}$ ramach programu LLP Erasmus. Doświadczenia gromadzone podczas takich wyjazdów były (i są do dzisiaj) prezentowane na spotkaniach w ramach tzw. Klubu pod Otwartą Księgą prowadzonego przez Koło Stowarzyszenia Bibliotekarzy Polskich (SBP) przy BUW. Dzięki tym obserwacjom dotyczącym m.in. form i tematyki szkoleń oraz współpracy z kadrą naukową przy ich tworzeniu, łatwiejsze okazało się planowanie określonych rozwiązań, jak również tworzenie szkoleń tematycznych (Nalewajska, 2012).

ANALIZA OFERTY EDUKACYJNEJ BIBLIOTEK WYDZIAŁOWYCH UNIWERSYTETU WARSZAWSKIEGO Z $2013 \mathrm{r}$.

W celu nakreślenia pełniejszego obrazu oferty szkoleń na UW autorka przeprowadziła w 2013 r. badanie ankietowe wśród bibliotek wydziałowych. Wykazało ono, że w większości prowadzono szkolenia o charakterze wstępnym, wprowadzającym studentów rozpoczynających studia w zasady korzystania ze zbiorów i usług, w formie jednorazowych spotkań. Tylko jedna biblioteka (poza BUW) oferowała szkolenie online, w kilku oferowano indywidualne konsultacje (Nalewajska, 2013). Wciąż zatem stopień zaawansowania dydaktyki w bibliotekach UW (tj. brak osadzenia szkoleń w programie studiów, zróżnicowania metod nauczania, edukowania tematycznego lub na zamówienie wykładowców) wydawał się niski.

\section{BADANIE DIAGNOSTYCZNE - METODOLOGIA I OPIS}

Przy projektowaniu oferty edukacyjnej istotne jest poznanie opinii, nawyków, posiadanych umiejętności oraz potrzeb informacyjnych odbiorców szkoleń. Aby lepiej poznać preferencje studentów rozpoczynających studia oraz kontynuujących edukację wyższa, autorka przeprowadziła badanie dotyczące form szkoleń (dostępne online lub prowadzone na miejscu w bi- 
bliotece; punktowane [punkty ECTS] ${ }^{11}$ lub niepunktowane; jednorazowe, cykliczne lub kilkuetapowe), ich tematyki oraz potrzeb informacyjnych studentów, w którym wykorzystano strategie badań ilościowych. Spośród metod sondażu diagnostycznego badanie ankietowe wydało się najbardziej adekwatne do zebrania informacji o zachowaniach i potrzebach informacyjnych studentów UW. Podczas przygotowywania kwestionariusza ankiet, autorka kierowała się: obserwacjami z poprzednich edycji szkoleń bibliotecznych prowadzonych na miejscu w BUW i w bibliotekach wydziałowych oraz dostępnych online, pytaniami użytkowników, informacjami dotyczącymi edukacji informacyjnej prowadzonej w bibliotekach wydziałowych UW oraz wiadomościami zaczerpniętymi z literatury. Należy podkreślić, że w BUW nie prowadzono wcześniej badań o podobnym charakterze ${ }^{12}$.

Jako termin przeprowadzenia badania wybrano semestr II roku akademickiego 2012/2013. Założeniem było, by studenci I roku I stopnia zdążyli już poznać funkcjonowanie systemu bibliotecznego uczelni i z niego skorzystać, w tym mieli m.in. możliwość uczestniczenia w szkoleniach bibliotecznych (oferowanych na miejscu w BUW, w bibliotekach wydziałowych, instytutowych lub w formie online), jak również mieli już za sobą zaliczenia, egzaminy lub prace pisemne, do których należało zgromadzić materiały, a zatem skorzystać z zasobów informacyjnych bibliotek. Wymienione uwarunkowania były tym bardziej oczywiste w stosunku do studentów rozpoczynających II stopień studiów, a więc mających już za sobą przygotowanie pracy licencjackiej. W tym przypadku chodziło o poznanie opinii bardziej świadomych i doświadczonych użytkowników, o większej samodzielności i potrzebach badawczych, posiadających już bardziej krytyczny stosunek do oferty i możliwości edukacyjnych jednostek uczelni, w tym bibliotek. Grupa respondentów liczyła łącznie 352 osoby, z czego 225 osób to studenci I roku I stopnia ${ }^{13}$, oraz 127 osób ${ }^{14}$ studiujących na I roku studiów II stopnia. Ankieta skierowana była przede wszystkim do studentów wydziałów zlokalizowanych najbliżej BUW, jako użytkowników potencjalnie najczęściej odwiedzających Bibliotekę. Kwestionariusz składał się z 8 pytań oraz z pytania dodatkowego skierowanego do studentów kontynuujących studia, a także krótkiej metryczki (pytanie o płeć; kierunek oraz rok studiów wpisane były na gotowych kwestionariuszach skierowanych do poszczególnych grup ankietowanych).

\footnotetext{
${ }^{11}$ Już w 2012 r. OIN wystąpił do władz rektorskich UW o wprowadzenie szkolenia bibliotecznego online do systemu USOS jako przedmiotu, któremu przyznawane są punkty ECTS, na co nie uzyskał zgody.

${ }_{12}$ Zakres kompetencji informacyjnych studentów trzeciego stopnia na UW badała Z. Wiorogórska (Wiorogórska, 2013a, 2013b, 2014).

${ }^{13}$ Badaniem objęto studentów Wydziałów: Historycznego (w tym Instytutów Historycznego, Informacji Naukowej i Studiów Bibliologicznych, oraz Historii Sztuki), Pedagogiki, Filozofii i Socjologii, Polonistyki (w tym Instytutu Filologii Klasycznej oraz Instytutów Polonistyki i Slawistyki).

${ }^{14}$ Byli to studenci Wydziałów Pedagogicznego oraz Historycznego (Instytutów: Historycznego oraz Informacji Naukowej i Studiów Bibliologicznych).
} 
Badanie wykazało, że respondenci najczęściej korzystają z bibliotek uczelni kilka razy w miesiącu, przy czym studenci II stopnia częściej odwiedzali biblioteki wydziałowe/instytutowe niż BUW, co wynika zapewne z większej specjalizacji mniejszych księgozbiorów oraz faktu, że biblioteki wydziałowe/instytutowe są zlokalizowane na miejscu, w tych samych budynkach, gdzie studenci mają zajęcia. Fakt ten stanowi zatem odpowiednią sposobność do rozszerzenia oferty szkoleniowej pogłębiającej umiejętności informacyjne użytkowników przez biblioteki poszczególnych jednostek uczelni. Niepokojący wydał się jednak stosunkowo duży odsetek studentów w ogóle niekorzystających z zasobów i pomocy uczelnianych książnic ${ }^{15}$. Może to wskazywać na bezkrytyczne poleganie jedynie na źródłach informacji wyszukiwanych przez wyszukiwarkę Google $\mathrm{w}$ otwartym Internecie, słabej orientacji w możliwościach wyszukiwania informacji w zasobach bibliotek (zarówno tradycyjnych, jak i elektronicznych) przez studentów lub braku takiej potrzeby (studenci otrzymują zestawienia potrzebnych materiałów lub gotowe materiały $\mathrm{w}$ formie kopii papierowej bądź elektronicznej).

Zapytano o uczestnictwo studentów w szkoleniu bibliotecznym na początku roku akademickiego lub na początku studiów. Ze względu na fakt, że na UW brak jednolitych ustaleń dotyczących obowiązku lub jego braku, jeśli chodzi o edukację biblioteczna, decyzja o szkoleniu bibliotecznym na początku studiów zależy od wydziału, a nierzadko instytutu. Dominują szkolenia prowadzone w bibliotekach wydziałowych/instytutowych (uczestniczyło w nich 35,13\% respondentów - studentów I stopnia oraz 21,42\% studentów II stopnia) oraz w wersji online, dotyczące korzystania z BUW (uczestniczyło 19,81\% respondentów - studentów I stopnia oraz 6,34\% studentów II stopnia). Należy jednak zauważyć, że duży odsetek ankietowanych studentów (17,56\% - studenci I stopnia, 40,47\% - studenci II stopnia) uczestniczył w podwójnym szkoleniu prowadzonym zarówno w bibliotece wydziałowej/instytutowej, jak i na miejscu w BUW. Badając tę kwestię zapytano studentów II stopnia o ocenę przydatności takich wstępnych szkolen prowadzonych przez BUW i biblioteki wydziałowe UW oraz to, czy ich zakres okazał się wystarczający na okres całego toku studiów i czy szkolenia te odpowiadały potrzebom informacyjnym studentów. 33,94\% respondentów uznało, że jednorazowe szkolenie wstępne było wystarczające, nieco więcej osób - 44,03\%, mimo pozytywnej odpowiedzi, potrzebowało wyjaśnień i dodatkowych informacji w późniejszym czasie. Za niewystarczające i niesatysfakcjonujące takie szkolenie uznało

15 Mimo zróżnicowania wyników warto wymienić: - I stopień: 33,33\% studentów Instytutu Filologii Polskiej nie korzystało z biblioteki wydziałowej; 36,66\% studentów Wydziału Dziennikarstwa nie korzystało z BUW; po 25\% studentów Wydziału Pedagogicznego nie korzystało ani z biblioteki wydziałowej ani z BUW; - II stopień: 56,09\% studentów Instytutu Informacji Naukowej i Studiów Bibliologicznych nie korzystało z biblioteki instytutowej; 22,44\% studentów pedagogiki nie korzystało z BUW. 
łącznie ponad 20\% respondentów, przy czym dla 11\% szkolenie było zbyt przeładowane informacjami w stosunku do czasu jego trwania i prowadzone bez możliwości praktycznego sprawdzenia omawianych zagadnień. 10,09\% wybrało odpowiedź zdecydowanie negatywną uznając, że szkolenie nie pomogło ani w korzystaniu z zasobów biblioteki, ani w wyszukiwaniu informacji. Zatem łącznie ponad 30\% respondentów oceniło szkolenie negatywnie. Informacje te wskazywały, że szkolenia powinny obejmować mniejszy zakres materiału i być silniej ukierunkowane tematycznie. Brak efektywności szkoleń o charakterze jednorazowym potwierdzają badania prowadzone w innych krajach (Mery \& al., 2012, s. 368-369).

Aby poznać opinie i potrzeby informacyjne studentów, zapytano, czy biblioteka akademicka powinna oferować szkolenia biblioteczne o zróżnicowanej tematyce, tj. obejmujące materiał odpowiadający potrzebom studentów I, II, III stopnia; przybliżające zagadnienia takie jak: ogólna charakterystyka biblioteki i zbiorów, źródła informacji, narzędzia wyszukiwawcze (katalogi, narzędzia wyszukiwawcze), zasoby (tradycyjne, elektroniczne), narzędzia do zarządzania bibliografią (por. Tab. 1).

Czy biblioteki uczelniane powinny oferować zróżnicowane szkolenia?

(Odpowiedzi ujęte procentowo).

\begin{tabular}{|l|c|c|}
\hline & $\begin{array}{c}\text { I stopień } \\
\text { studiów }\end{array}$ & $\begin{array}{c}\text { II stopień } \\
\text { studiów }\end{array}$ \\
\hline Raczej tak & 36,00 & 30,15 \\
\hline Zdecydowanie tak & 20,88 & 31,74 \\
\hline Raczej nie - wystarczy szkolenie ogólne na początku I roku & 30,22 & 34,12 \\
\hline $\begin{array}{l}\text { Zdecydowanie nie - nie widzę potrzeby uczestniczenia w takich } \\
\text { szkoleniach, wszystko mogę znaleźć samodzielnie w Internecie }\end{array}$ & 12,88 & 3,96 \\
\hline
\end{tabular}

Źródło: Oprac. własne na podstawie badań.

Należy zauważyć, że studenci I roku studiów magisterskich w większości pozytywnie (łącznie 61,89\%) opowiedzieli się za szeroką ofertą edukacyjną w bibliotekach. W kontekście większego doświadczenia oraz pogłębionych potrzeb informacyjnych tej grupy respondentów, fakt ten jest inspirujący do podejmowania dalszych działań przez biblioteki. Podobny odsetek studentów na poziomie licencjatu oraz studiów magisterskich wskazał, że raczej nie ma potrzeby rozbudowy oferty szkoleniowej przez biblioteki. Jest to niepokojące, bowiem dla osób, które, jak się wydaje, powinny pogłębiać swoje kompetencje informacyjne oraz medialne, wystarczające okazują się, w ich opinii, ogólne szkolenia wstępne. Może to wskazywać na kilka aspektów: brak zainteresowania, potrzeby i świadomości konieczności pogłębiania swoich umiejętności informacyjnych przez studentów; wysoką samoocenę własnych umiejętności w zakresie 
korzystania z zasobów informacyjnych bibliotek i posługiwania się nimi; brak wskazówek ze strony prowadzących zajęcia pracowników naukowych o takiej ofercie bibliotecznej; czy wreszcie brak współpracy przy budowaniu oferty edukacyjnej między pracownikami naukowymi a bibliotekami.

Jak wspomniano, na UW to władze wydziałów i instytutów decydują o tym, czy szkolenie biblioteczne jest obowiązkowe, czy nie. Z punktu widzenia bibliotek celowym jest więc poznanie opinii samych studentów, czy i w jakim stopniu są oni zainteresowani włączeniem edukacji informacyjnej do swojego curriculum - takie rozwiązanie zdecydowanie wybrało 23,55\% studentów I stopnia i 30,15\% studentów II stopnia. Odsetek przeciwników był znacznie większy i wyniósł odpowiednio 53,77\% oraz $48,41 \%$ respondentów. Badania zagraniczne (post-testy) wykazują natomiast większą efektywność szkoleń punktowanych, także w formie online (Mery et al., 2012, p. 369).

$\mathrm{Z}$ treścią powyższego pytania skorelowane zostały kolejne, dotyczące najkorzystniejszych, w opinii respondentów, form oraz tematyki szkolenia bibliotecznego. Spośród trzech form szkoleniowych: online, na miejscu $\mathrm{w}$ bibliotece $\mathrm{z}$ biernym uczestnictwem oraz szkolenie $\mathrm{w}$ bibliotece z uczestnictwem aktywnym, najwięcej osób opowiedziało się za tą ostatnią formą (49,09\% studentów I stopnia i 53,6\% studentów II stopnia). Pozostałe formy uzyskały zbliżone wyniki oscylujące w granicach dwudziestu kilku procent w każdej z grup respondentów. Jak pokazują przykłady rozwiązań stosowanych w bibliotekach zagranicznych uczelni, studenci uczestniczący w zajęciach ukierunkowanych na ich konkretne potrzeby informacyjne (ang. student-driven approach) oraz aktywizujących (łączących zróżnicowane formy: od prezentacji, dyskusji, tworzenia blogów, czy nagrań wideo, przez edytowanie tekstów w Wikipedii, po kreślenie map myśli) nie tylko wyzwalają kreatywność i zaangażowanie, lecz nade wszystko uświadamiają uczestnikom takich zajęć praktyczne znaczenie edukacji informacyjnej w ich życiu. Rozwijają także inne umiejętności, m.in. współpracy czy medialne (Bond, 2016). Pomimo wszechobecności źródeł elektronicznych i, jakby się wydawało, ich zdecydowanej dominacji nad tradycyjnymi zasobami informacji, badanie wyraźnie ujawniło potrzebę interakcji pomiędzy uczestnikiem a prowadzącym zajęcia bibliotekarzem. Okazuje się, że szkolenia online, mimo ich dostępności o dowolnej porze, $\mathrm{w}$ dowolnym miejscu, nie zapewniają, w opinii studentów, wystarczającej efektywności. Zarówno studenci na początku studiów, jak i kontynuujący edukację na II poziomie wyraźnie preferują aktywną formę szkolenia w bibliotece $\mathrm{z}$ możliwością prowadzenia dialogu z prowadzącym, zamiast wirtualnego tutorialu. Literatura zagraniczna podaje przykłady badań efektywności różnych metod dydaktycznych stosowanych w edukacji informacyjnej (Greer et al., 2016; Anderson \& May, 
2010; Zhang et al., 2007; Silver \& Nickel, 2007). Najczęściej porównywane metody to: tutoriale online, szkolenia prowadzone face-to-face oraz formy mieszane. Należy jednak podkreślić, że badana jest efektywność szkoleń osadzonych w konkretnym kontekście edukacyjnym, tj. przygotowywanych i prowadzonych pod kątem wybranych zajęć, najczęściej wraz z wykładowcami, co stanowi zasadniczą różnicę $\mathrm{w}$ podejściu do dydaktyki (program zajęć, metodologia, ocena efektywności) w stosunku do realiów większości polskich bibliotek uczelnianych.

W pytaniu o tematy szkoleń, w których studenci chcieliby uczestniczyć, istniała możliwość wielokrotnego wyboru (Tab. 2). Uwagę zwraca największe zainteresowanie szkoleniami dziedzinowymi, co, w przypadku studentów na II stopniu studiów, wyraźnie pokazuje, że brakuje specjalistycznych, ukierunkowanych tematycznie kursów oferowanych przez biblioteki. Zbliżony wynik w obydwu grupach ankietowanych przy szkoleniu dotyczącym narzędzi wyszukiwawczych także wyraźnie wskazuje kierunek, w którym powinny podążyć biblioteki planując działania edukacyjne. Ponad to poproszono respondentów o podanie własnych propozycji tematów szkoleń. Nie było ich wiele. Studenci studiów I stopnia zasugerowali następujące tematy (sformułowania zaczerpnięto $\mathrm{z}$ ankiet): „źródła zdigitalizowanych książek, tekstów; tworzenie bibliografii; dotyczące zasobów źródłowych i archiwalnych biblioteki; Open Access; zarządzanie bibliografią". W przypadku studentów II stopnia udzielono tylko jednej odpowiedzi: „Przygotowujących do praktycznej pracy naukowej i obejmujących powyższe (podane $\mathrm{w}$ tabeli - LN), z naciskiem na źródła zagraniczne oraz narzędzia do zarządzania i wyszukiwania bibliografii“”

Tabela 2

W jakich szkoleniach oferowanych przez BUW chciałabyś/chciałbyś uczestniczyć?

(Odpowiedzi ujęte procentowo).

\begin{tabular}{|l|c|c|}
\hline Rodzaj szkolenia & $\begin{array}{c}\text { I rok studiów } \\
\text { licencjackich }\end{array}$ & $\begin{array}{c}\text { I rok studiów } \\
\text { magisterskich }\end{array}$ \\
\hline Ogólne, wprowadzające w zasady korzystania z biblioteki & 28,95 & 44,71 \\
\hline Dotyczące zasobów elektronicznych & 21,26 & 46,34 \\
\hline $\begin{array}{l}\text { Dziedzinowe, specjalistyczne dot. zasobów tradycyjnych i elek- } \\
\text { tronicznych }\end{array}$ & 37,55 & 50,4 \\
\hline Dotyczące źródeł informacji & 24,88 & 30,08 \\
\hline Dotyczące narzędzi wyszukiwawczych & 36,65 & 37,39 \\
\hline Innych & 2,71 & 9,75 \\
\hline
\end{tabular}

Źródło: Oprac. własne na podstawie badań.

Szczególną uwagę należy zwrócić na sugestie płynące ze strony studentów II stopnia, którzy z perspektywy większego doświadczenia, z silniejszą świadomością wskazują na chęć udziału w szkoleniach dotyczących 
zasobów elektronicznych oraz specjalistycznych. Natomiast duży procent odpowiedzi, wskazujący na zainteresowanie szkoleniami ogólnymi i wprowadzającymi, może wynikać z faktu, że studenci II stopnia poziom licencjacki ukończyli na innej uczelni lub na innym wydziale UW, gdzie takie szkolenia nie były prowadzone.

\section{NOWA OFERTA SZKOLENIOWA}

Wyniki przedstawionego badania ankietowego zostały wykorzystane jako wskazówka przy tworzeniu nowej oferty szkoleniowej w 2014 r. $\mathrm{W}$ drugiej połowie tego roku uruchomiony został cykl szkoleń tematycznych pod hasłem: „Wiedza nie leży na ulicy, znajdziesz ją w BUW!”. Zaproponowano osiem tematów: Mocna strona Internetu. Zasoby elektroniczne na Uniwersytecie Warszawskim; Jak szukać, by nie błądzić, czyli o sposobach wyszukiwania w katalogu online bibliotek UW; Elektroniczne bazy prawnicze na UW; Jak sobie poradzić z listą lektur?; Porządek rzeczy, czyli jak sporządzać przypisy i bibliografię załącznikową; Zasoby elektroniczne dla historyków sztuki i architektury dostępne na UW - podstawowe wiadomości; Legalnie do celu - o prawie autorskim w nauce; Zbieranie literatury do pracy z pedagogiki? To nie jest takie trudne! Opracowano logo, poster oraz krótki film promujący szkolenia ${ }^{16}$. W $2014 \mathrm{r}$. przeszkolono 100 osób, głównie studentów i pracowników naukowych, również spoza UW (Sprawozdanie OUiS, 2014, s. 6). W roku następnym kontynuowano tematy szkolen' ${ }^{17}$ i przeszkolono ogółem 65 osób (Sprawozdanie OUiS, 2015).

\section{BADANIE DIAGNOSTYCZNE - METODOLOGIA I OPIS}

Zainteresowanie ofertą szkoleniową BUW wydawało się nadal niesatysfakcjonujące. W ciągu całego 2016 r. przeprowadzono 22 tematyczne szkolenia dziedzinowe dla 93 osób (Sprawozdanie OUiS, 2016). Aby pogłębić informacje na temat potrzeb użytkowników autorka przeprowadziła kolejne badanie ankietowe w I semestrze roku akademickiego 2015/2016, ale już tylko wśród studentów I roku I stopnia ${ }^{18}$. Grupa respondentów liczyła łącznie 389 osób. Przygotowano ankietę składającą się z 25 pytań.

\footnotetext{
${ }^{16} \mathrm{https} / / /$ www.youtube.com/watch?v=YBnVOUUE0mM

${ }_{17}$ Poza dotyczącym gromadzenia literatury z pedagogiki ze względu na odejście prowadzącej na emeryturę.

${ }^{18}$ Badaniem objęto studentów I stopnia Wydziałów: Historycznego (Instytutu Historii Sztuki oraz Instytutu Informacji Naukowej i Studiów Bibliologicznych), Wydziału Lingwistyki Stosowanej (Instytutów Rusycystyki i Germanistyki), Wydziału Polonistyki, Wydziału Filozofii i Socjologii, Ośrodka Studiów Amerykańskich, Międzywydziałowych Studiów Ochrony Środowiska oraz pojedyncze osoby z Międzywydziałowych Indywidualnych Studiów Humanistycznych, Wydziału Prawa, Wydziału Fizyki. W metryczce zapytano o miejsce zamieszkania respondentów: 41,6\% było z Warszawy, 58,4\% spoza stolicy; $73,3 \%$ to kobiety, $26,7 \%$ - mężczyźni.
} 
Pytania zawarte w kwestionariuszu dotyczyły, po części, zagadnień zbliżonych do poruszanych w I badaniu diagnostycznym z roku 2012/2013. Jednakże w celu głębszego poznania potrzeb i umiejętności informacyjnych studentów oraz lepszego dostosowania oferty edukacyjnej bibliotek, poszerzono kwestionariusz ankiety o pytania dotyczące: zdobytych na poziomie szkoły podstawowej i średniej kompetencji informacyjno-medialnych; doświadczenia $\mathrm{w}$ wyszukiwaniu oraz korzystaniu z zasobów informacji dostępnych w Internecie na poziomie szkoły średniej, a szczególnie w klasie maturalnej; kompetencji językowych (poznanie oceny poziomu znajomości języków obcych może być przydatne w konstruowaniu szkoleń z zakresu zasobów elektronicznych oferujących publikacje zagraniczne, czy np. narzędzi do zarządzania bibliografią z obcojęzycznymi interfejsami); kompetencji medialnych (ocena umiejętności korzystania z komputera, zasobów sieci Internet, wyszukiwania informacji i oceny ich przydatności). Pytania ogólne mające na celu opracowanie podstawowej charakterystyki respondentów dotyczyły: korzystania z bibliotek publicznych, miejsca zamieszkania (w Warszawielub poza), płci, kierunku studiów.

Jednym z zamierzeń było zbadanie, $w$ jakim stopniu realizowano edukację informacyjną wobec faktu, że Podstawa programowa kształcenia ogólnego z 2009 r. (MENiS, 2009a; MENiS, 2009b) zniosła z programu nauczania edukację czytelniczą i medialną oraz wyeliminowała biblioteki szkolne z procesu kształcenia dzieci i młodzieży (Brzezińska, 2008, s. 5), oddając odpowiedzialność za realizację edukacji informacyjnej nauczycielom ${ }^{19}$. Wydaje się bowiem, że dobre nawyki i umiejętności informacyjno-medialne, wykształcone właśnie na poziomie szkoły podstawowej i średniej moga, a wręcz powinny, przekładać się na pogłębione kompetencje informacyjne uczniów kończących edukację szkolną. Biblioteki akademickie, naukowe „które w naturalny sposób kontynuują działalność edukacyjną bibliotek szkolnych, ucząc ich absolwentów edukacji informacyjnej i medialnej już na wyższym poziomie trudności" (Kostecka, 2015, s. 30) mają za zadanie poszerzanie horyzontów myślowych oraz rozwijanie umiejętności i kultury informacyjnej poprzez zajęcia edukacyjne. Lekcje biblioteczne w szkołach można zatem traktować jako wstępny etap rozwijania umiejętności informacyjnych i zachętę do uczestnictwa w edukacji

${ }^{19}$ Większość sugerowanych treści z zakresu edukacji czytelniczej i medialnej dopisano do różnych przedmiotów. Podstawa programowa dla szkół podstawowych z 2017 r. również nie rozwija zaleceń dotyczących edukacji czytelniczej. Do najważniejszych umiejętności rozwijanych w ramach kształcenia ogólnego w szkole podstawowej zalicza m.in.: „poszukiwanie, porządkowanie, krytyczną analizę oraz wykorzystanie informacji z różnych źródeł", a jednym z celów samokształcenia ucznia ma być „rozwijanie umiejętności efektywnego posługiwania się technologią informacyjną w poszukiwaniu, porządkowaniu i wykorzystywaniu pozyskanych informacji"; efektem samokształcenia ucznia ma być to, że „zna i stosuje zasady korzystania z zasobów bibliotecznych (np. w bibliotekach szkolnych oraz online)" oraz "rozwija umiejętności efektywnego posługiwania się technologią informacyjną oraz zasobami internetowymi i wykorzystuje te umiejętności do prezentowania własnych zainteresowań" (MEN, 2017). 
bibliotecznej na późniejszym etapie edukacji. Niestety, brak odpowiedniej edukacji bibliotecznej na poziomie szkolnictwa podstawowego i średniego przekładać się może na niewielkie zainteresowanie taką ofertą na późniejszym etapie, co zdaje się potwierdzać mała liczba uczestników, po uruchomieniu poszerzonej oferty szkoleniowej w BUW w 2014 r. ${ }^{20}$. Problem ten znalazł odzwierciedlenie w wynikach II badania, gdzie zapytano o uczestniczenie w lekcjach bibliotecznych w szkole. Uzyskano następujące rezultaty: tak, tylko w szkole podstawowej-24,4\%; tak, w szkole podstawowej i średniej - 34,2\%; tylko w szkole średniej-6,7\%; nie, nie było takich szkoleń - 32,1\%; nie, nie byłam/em zainteresowana/y - 2,6\%. Odpowiedzi ujawniły stosunkowo wysoki odsetek braku lekcji bibliotecznych w szkole podstawowej i średniej. Studenci, którzy nie uczestniczyli wcześniej w zajęciach bibliotecznych, zwyczajnie mogą nie zdawać sobie sprawy, że również biblioteki realizują zadania edukacyjne.

Nawiązując do wcześniejszej ankiety, zapytano o najbardziej efektywną w opinii respondentów, formę szkoleń. Dzięki poznaniu preferencji użytkowników można tworzyć atrakcyjne dla nich formy edukacyjne, przez co szkolenia będą miały większe szanse powodzenia. Podobnie, jak w badaniu I, preferowaną formą okazało się aktywne szkolenie prowadzone w bibliotece, dające możliwość bezpośredniego kontaktu z prowadzącym. Drugą w kolejności (31,9\%), preferowaną formą szkoleniową okazało się szkolenie w formie krótkich tutoriali ${ }^{21}$ (np. filmy na YouTube) lub gier. Na kolejnym miejscu uplasowało się szkolenie online udostępniane na platformie $\mathrm{w}$ trybie $24 / 7(22,1 \%)$, natomiast forma webinarium nie zyskała większego zainteresowania (9,8\%). Wyniki uzyskane w badaniu II potwierdziły rezultaty z wcześniejszego - respondenci uznali, że szkolenie na miejscu, $w$ interakcji z prowadzącym przyniesie najlepsze efekty. Taki rezultat może wynikać z dotychczasowego doświadczenia jeszcze na etapie edukacji szkolnej, gdzie z jednej strony uczniowie, obecnie już studenci, uczestniczyli w tradycyjnych lekcjach, z drugiej jednak strony w edukacji szkolnej w dużej mierze wykorzystuje się pomoce i różnorodne formy aktywności online. Przy projektowaniu szkoleń należy zatem brać pod uwagę dwie równoległe ścieżki - tradycyjną formę szkolenia na miejscu w bibliotece oraz skoncentrowaną na szczegółowych zagadnieniach formę wirtualnego, interaktywnego tutorialu lub gry.

Ponownie zapytano również o chęć oraz zasady uczestniczenia w szkoleniach oferowanych przez biblioteki. Zainteresowanie, pod warunkiem otrzymania punktu ECTS, wyraziło 32,1\% ankietowanych. Duży odsetek,

\footnotetext{
${ }^{20}$ W tym miejscu pomija się kwestie promocji oraz bliższej współpracy z kadrą naukową.

${ }^{21}$ Forma tutorialu online była dominująca wśród odpowiedzi w badaniu J. Davidson (Davidson, 2001). W warunkach polskich rzadko stosowane są gry biblioteczne (a jeśli już, to dzieją się one $\mathrm{w}$ przestrzeni fizycznej biblioteki), a tutoriale online nie mają form interaktywnych (pomijając pytania testowe).
} 
bo $27,5 \%$ respondentów, zadeklarował chęć odbycia szkoleń bez uzyskania punktu. 10\% odpowiedzi była negatywna, natomiast 30,8\% ankietowanych nie miała zdania w tej kwestii. Cieszy duży procent zainteresowanych szkoleniami. Studenci na początku procesu wyższej edukacji nie zdają sobie jeszcze sprawy ze znaczenia pogłębiania swoich umiejętności informacyjnych, korzystania ze źródeł informacji i ich oceny, dlatego ponad 30\% respondentów mogło jeszcze nie posiadać wyrobionej opinii na ten temat.

W badaniu zapytano także o tematykę oferowanych szkoleń (por. Tabela 3), jednak tym razem podano bardziej szczegółowe opisy proponowanych zajęć, co odpowiadało w dużej mierze tematyce szkoleń już funkcjonujących w BUW.

Czy jesteś zainteresowana/y szkoleniami dotyczącymi szczegółowych zagadnień?

\begin{tabular}{|l|c|}
\hline \multicolumn{1}{|c|}{ Rodzaj szkolenia } & $\%$ \\
\hline $\begin{array}{l}\text { Wyszukiwanie informacji (strategia wyszukiwania, ocena przydatności } \\
\text { i wiarygodności informacji) }\end{array}$ & 38,3 \\
\hline $\begin{array}{l}\text { Zasobów elektronicznych (korzystanie z baz, naukowych czasopism i książek } \\
\text { elektronicznych, wyszukiwanie informacji w bazach danych dostępnych na UW) }\end{array}$ & 35 \\
\hline Etyczne korzystanie z informacji (prawo autorskie - co, jak i kiedy można cytować) & 28 \\
\hline $\begin{array}{l}\text { Tworzenie bibliografii (poznanie narzędzi ułatwiających gromadzenie i tworzenie } \\
\text { bibliografii przy pisaniu pracy licencjackiej i magisterskiej) }\end{array}$ & 41,6 \\
\hline $\begin{array}{l}\text { Szkolenia przedmiotowe (dotyczące wyszukiwania i korzystania z zasobów } \\
\text { tradycyjnych oraz elektronicznych, np. z dziedziny prawa, nauk społecznych, } \\
\text { pedagogiki, historii, innych) }\end{array}$ & 23,4 \\
\hline $\begin{array}{l}\text { Szkolenia dotyczące korzystania z katalogu online bibliotek UW oraz poznanie } \\
\text { innych katalogów bibliotek krajowych i zagranicznych }\end{array}$ & 25,2 \\
\hline Nie jestem zainteresowana/y & 18,3 \\
\hline
\end{tabular}

Źródło: Oprac. własne na podstawie badań.

Należy w tym miejscu zwrócić uwagę, że tematem dominującym okazało się tworzenie bibliografii $(41,6 \%)$. Na drugim miejscu znalazło się wyszukiwanie informacji połączone z jej ewaluacją, co wskazuje na świadomość braku tych umiejętności oraz niewykształcenie ich na etapie edukacji szkolnej. Pokrywa się to również z dosyć niską oceną własnych umiejętności oceny przydatności i wiarygodności źródeł wyszukanych w sieci. Zarówno w I, jak i w II badaniu ankietowym, szkolenia z zakresu zasobów elektronicznych nie były najbardziej oczekiwane. Fakt ten potwierdza wysoką samoocenę respondentów dotyczącą ich umiejętności związanych z obsługą Internetu oraz wyszukiwania informacji w sieci.

Wydawać by się mogło, że $\mathrm{w}$ dobie nadmiarowości informacji, powstawania nowych kanałów informacji naukowej i badawczej, studenci - a część z tego grona zostanie przecież w przyszłości pracownikami na- 
ukowymi - powinni w większym stopniu interesować się możliwościami rozwijania swoich kompetencji oraz świadomości informacyjnej i poszukiwać ich. Porównanie wyników odpowiedzi dotyczących oferty szkoleń specjalistycznych, dziedzinowych z badania I i II wyraźnie pokazuje, że dopiero studenci na dalszym etapie kształcenia zauważają potrzebę rozwijania swoich umiejętności we wspomnianym zakresie (badanie I - studenci I stopnia 37,55\%, studenci II stopnia - 50,40\%; badanie II - 23,4\%).

Kolejne pytania zostały zgrupowane w bloku poświęconym korzystaniu z zasobów sieciowych. Miało to na celu sprawdzenie ogólnych umiejętności korzystania z zasobów elektronicznych dostępnych w sieci Internet (choć jest oczywiste, iż część z nich polecali nauczyciele) oraz korzystania $\mathrm{z}$ dostępnych $\mathrm{w}$ Internecie zasobów informacyjnych przydatnych uczniom, szczególnie na etapie klasy maturalnej. Dominującym źródłem informacji okazały się ogólne wyszukiwarki, a drugim w kolejności - Wikipedia. Wobec takiego rezultatu należałoby zapytać o stopień zaawansowania w korzystaniu $\mathrm{z}$ tego rodzaju źródeł. Można jednak zakładać, że z tych aparatów informacyjnych młodzież korzysta jedynie na poziomie podstawowym. Obecnie to Internet jest dla młodych ludzi podstawowym narzędziem komunikacyjnym oraz źródłem informacji wykorzystywanych również w procesie kształcenia. Jednak poza ogólnymi wyszukiwarkami, wykorzystanie tych zasobów informacyjno-edukacyjnych jest bardzo powierzchowne (badanie wykazało brak korzystania z portali: Wolnelektury.pl. - u 56,2\% respondentów, kursów maturalnych online $67,6 \%$, darmowych portali do nauki języków obcych online $-52,6 \%$, portali edukacyjnych - 43,3\%). Można zakładać, że system edukacji formalnej w niewystarczającym stopniu przygotowuje i uczy młodzież korzystania z wiarygodnych źródeł informacji dostępnych w sieci Internet. Nie jest zatem rozwijana w wystarczającym stopniu edukacja cyfrowa.

Kolejna grupa pytań koncentrowała się wokół zachowań informacyjnych. Respondenci oceniali w skali od 0 (brak) do 5 (bardzo wysokie) swoje umiejętności $\mathrm{z}$ zakresu wyszukiwania informacji w Internecie i w źródłach tradycyjnych oraz umiejętności oceny ich wiarygodności i przydatności (Tab. 4).

Drugim ocenianym zagadnieniem były kompetencje medialne - obsługa Internetu. Rezultaty pokrywają się z obserwacjami Fundacji Orange (Fundacja Orange, 2013): „[...] z deklaracji młodych ludzi wynika, że internet jest dla nich najważniejszym wparciem w zdobywaniu wiedzy. Dla $72 \%$ respondentów nauka bez internetu byłaby dużo trudniejsza, a $60 \%$ z nich potwierdza, że internet to dla nich główne źródło informacji przy nauce i odrabianiu prac domowych. [...] Niezależnie od częstotliwości korzystania z Internetu, młodzi postrzegają siebie jako biegłych użytkowników nowych technologii. Dobrze lub bardzo dobrze ocenią swoje kompetencje w zakresie obsługi Internetu (84\%), obsługi komputera (80\%) 
Jak oceniasz swoje umiejętności, w skali od 0 (brak umiejętności) do 5 (umiejętności bardzo wysokie), z zakresu (udział procentowy):

\begin{tabular}{|l|c|c|c|c|c|c|}
\hline & 0 & 1 & 2 & 3 & 4 & 5 \\
\hline Obsługa Internetu & 0 & 0 & 0,8 & 13,3 & 35 & 50,9 \\
\hline Wyszukiwania informacji w Internecie & 0 & 0,3 & 0,8 & 11,8 & 44,7 & 42,4 \\
\hline $\begin{array}{l}\text { Wyszukiwania informacji w źródłach } \\
\text { tradycyjnych }\end{array}$ & 0 & 1,9 & 13,8 & 32,6 & 36,1 & 15,6 \\
\hline $\begin{array}{l}\text { Oceny przydatności i wiarygodności } \\
\text { wyszukanych w sieci źródeł }\end{array}$ & 0,5 & 2,9 & 12,6 & 34,5 & 33,7 & 15,8 \\
\hline
\end{tabular}

Źródło: Oprac. własne na podstawie badań.

i wyszukiwania informacji w Internecie (80\%). [...] Do informacji znajdowanych w Internecie i swoich kompetencji w zakresie ich weryfikacji młodzi podchodzą z różną dozą zaufania: $65 \%$ ocenia, że informacje, które znajduje w sieci, są wiarygodne, ale $79 \%$ weryfikuje je w innych źródłach (np. 15\% weryfikuje informacje zdobyte w Internecie w oparciu o książki lub encyklopedie, a $24 \%$ - poszukując innych źródeł w sieci). Jednak 21\% młodych osób w ogóle nie sprawdza, czy wiadomości, które znajdują w sieci, są prawdziwe" 22 .

W swoim badaniu ankietowym prowadzonym wśród studentów UW autorka poprosiła także o ocenę kompetencji językowych, a głównie określenie poziomu znajomości języka angielskiego. Wiąże się to z przyszłym korzystaniem z literatury obcojęzycznej oraz zasobów elektronicznych (w większości publikowanych w językach obcych, głównie angielskim), jak również planowaniem szkoleń dotyczących korzystania z e-zasobów czy narzędzi do zarządzania bibliografią posiadających obcojęzyczne interfejsy.

W skali od 0 do 5 ( 0 - brak znajomości, 5 - znajomość bardzo dobra) $25,8 \%$ respondentów oceniło swoje umiejętności na poziomie 3; 36,7\% - na 4; a 30,5\% - na 5. Wobec szeroko prowadzonej edukacji językowej, szczególnie z zakresu języka angielskiego, trwającej od poziomu edukacji przedszkolnej, a już z pewnością obowiązkowej od początku szkoły podstawowej, wynik samooceny wydaje się rozczarowujący. Zaledwie jedna trzecia respondentów ocenia swoje umiejętności na najwyższym poziomie. To może wyjaśniać, dlaczego stopień wykorzystania obcojęzycznych zasobów elektronicznych, pomimo notowanego wzrostu, nadal pozostaje niesatysfakcjonujący, szczególnie $\mathrm{w}$ kontekście ponoszonych na ten cel nakładów finansowych.

\footnotetext{
${ }^{22}$ Badanie „Kompetencje młodzieży w Polsce” zostało zrealizowane w dniach 12-30 sierpnia 2013 r. przez TNS Polska na zlecenie Orange Polska na losowej, reprezentatywnej próbie 600 osób w wieku 14-18 lat. Jednocześnie przeprowadzano wywiady z dziećmi oraz jednym z rodziców. Wywiady realizowano w gospodarstwach domowych posiadających dostęp do Internetu.
} 
Jako dodatkową grupę należy potraktować trzy kolejne pytania badające opinię respondentów na temat bibliotek. I tak niemal $88 \%$ ankietowanych uważa, że biblioteka jest dobrym miejscem do rozwijania umiejętności ułatwiających proces kształcenia (wyszukiwanie informacji, korzystanie z katalogów). Napawa to optymizmem i zachęca do rozwijania działalności bibliotek w kierunku edukacji użytkowników ${ }^{23}$.

Nawiązując do początkowych pytań o częstotliwość korzystania z bibliotek wydziałowych/instytutowych oraz z zasobów BUW, zapytano o to, jak często ankietowani korzystali z biblioteki szkolnej, szczególnie $\mathrm{w}$ klasie maturalnej. Wyniki pokazały, że codziennie $2,3 \%$ respondentów; kilka razy w tygodniu - 18,8\%; kilka razy w miesiącu - 40,4\%; kilka razy w roku - 26,7\%; w ogóle nie korzystało - 12,1\%. Niepokojący jest stosunkowo wysoki odsetek osób, które nie odwiedzały swoich bibliotek przed egzaminem maturalnym. Można to jednak tłumaczyć faktem, że zamiast z bibliotek szkolnych osoby te korzystały ze zbiorów bibliotek publicznych, bo jak pokazały odpowiedzi na pytanie dotyczące korzystania z książnic publicznych $70 \%$ respondentów korzysta z ich zasobów, pozostała część nie ma takiej potrzeby.

\section{KURS „NAPISZ Z NAMI TEKST NAUKOWY”}

Po przeprowadzonym badaniu kolejnym etapem była rozbudowa oferty szkoleniowej. W połowie $2016 \mathrm{r}$. rozpoczęły się w OUiS BUW prace nad stworzeniem kursu skierowanego przede wszystkim do studentów i doktorantów, omawiającego kompleksowo etapy pisania tekstu naukowego (m.in. pracy dyplomowej, artykułu, pracy zaliczeniowej, tekstu konferencyjnego). Powstało sześć modułów:

- moduł 1 obejmujący zagadnienia: Formułowanie tematu badawczego; Konkretyzacja przedmiotu badań; Dobór metodologii; Rodzaje prac dyplomowych;

- moduł 2: Struktura pracy dyplomowej; Edycja tekstu; Wstęp do zasad poprawności językowej;

- moduł 3 (podzielony wg tematyki dziedzinowej): Źródła informacji i ich selekcja - podstawy; "Zaloguj się do wiedzy” - e-zbiory w sieci UW; Wyszukiwanie literatury do prac z zakresu nauk humanistycznych/nauk ścisłych/prawa/filologii (do wyboru);

- moduł 4: Przypisy i bibliografia załącznikowa;

- moduł 5: Mendeley - menedżer bibliografii;

- moduł 6: Jak pisać i publikować w zgodzie z prawem i etyką? (Sprawozdanie OUiS, 2017, s. 18).

\footnotetext{
${ }^{23} 11 \%$ respondentów nie miało na ten temat zdania, a tylko $1 \%$ udzielił negatywnej odpowiedzi.
} 
Do końca 2016 r. opracowane zostały prezentacje, rozpoczęto promocję kursu, który uruchomiono na początku roku następnego (Sprawozdanie OUiS, 2016, s.11). Kurs, podzielony na tematyczne moduły, realizowany był w kolejne dni tygodnia - raz w miesiącu. Zainteresowani mogli uczestniczyć w całym kursie lub w wybranych modułach. Od stycznia do maja 2017 r. skorzystało z niego na miejscu w BUW 765 osób oraz 432 osoby podczas szkoleń zamawianych przez jednostki UW (na wydziałach lub w BUW, ale poza ustalonym grafikiem). Dodatkowo w szkoleniu wzięło udział 26 studentów z UKSW oraz 39 osób podczas pojedynczych szkoleń poza grafikiem. Łącznie przeszkolono 1262 osoby. Jako formy dydaktyczne dla części modułów wybrano metodę podającą (wykład informacyjny), dla pozostałych metody warsztatowe z użyciem komputerów. Pomimo dużego zainteresowania kursami zauważono, że tworzenie modułowych bloków trwających tydzień nie jest wygodne dla uczestników - trudno im dostosować grafik swoich zajęć do ustalonej oferty. Aby ułatwić użytkownikom skorzystanie ze szkoleń, zmodyfikowano w roku akademickim 2017/2018 sposób prowadzenia zajęć - zrezygnowano z modułów na rzecz pojedynczych szkoleń prowadzonych planowo raz w miesiącu - w godzinach przedpołudniowych na zmianę z popołudniowymi (co drugi miesiąc). Ponadto zrezygnowano z modułu 1 dotyczącego formułowania tematu badawczego oraz z modułu 2 (z powodu odejścia z pracy osoby prowadzącej). Zaoferowano natomiast nowe zajęcia: MSWord dla piszących teksty naukowe; Krótki kurs obsługi Citavi; Ekonomia \& Biznes. Wybrane zasoby elektroniczne UW; Tradycyjne i internetowe źródła wiedzy o antyku - wykład i warsztaty; Poszukajmy wspólnie - warsztaty z wyszukiwania dla studentów młodszych lat kierunków humanistycznych i filologicznych. Łącznie w ofercie znajduje się 20 kursów (Sprawozdanie OUiS, 2017, s. 22).

Ponadto w 2017 r. ofertę szkoleniową wzbogacono o kursy dotyczące oceny wyników działalności naukowej: Bibliometria oraz Altmetria, jak również podstawowe szkolenie z zakresu prawa autorskiego. W okresie listopad - grudzień 2017 r. w zajęciach uczestniczyło 100 osób (Sprawozdanie OUiS, 2017, s. 24). Rozkład zainteresowania tematami szkoleń odpowiada wynikom ankiet - najwięcej osób uczestniczyło w szkoleniach dotyczących zasobów elektronicznych oraz menadżerów bibliografii, jak i wyszukiwania informacji.

\section{WNIOSKI. PODSUMOWANIE}

Analiza kilkuletniego procesu tworzenia oferty dydaktycznej w BUW ujawniła, jak wieloaspektowe musi być podejście przy tego typu zadaniach. Pokazała również strony mocne (m.in. gotowość pracowników do podejmowania nowych ról i stawania się edukatorami, nauczycielami) oraz te słabsze poszczególnych elementów procesu (m.in. poczucie biblio- 
tekarzy swych niepełnych kompetencji dydaktycznych przy ograniczonych możliwościach ich rozwijania i doskonalenia - brak odpowiednich szkoleń, deficyt czasu; zbyt słaba współpraca z wydziałami; mała efektywność promocji). Projektując ofertę dydaktyczną należy rozpatrywać perspektywy: zewnętrzną - postrzeganie zakresu proponowanych treści oraz form szkoleń przez użytkowników oraz wewnętrzną - analiza kontekstu edukacyjnego, w którym będą osadzone szkolenia, technik nauczania oraz rzeczywistych potrzeb informacyjnych użytkowników, a po uruchomieniu oferty edukacyjnej poddanie jej ewaluacji (post-testy) w celu tworzenia nowych lub udoskonalania już funkcjonujących programów i szkoleń (Kim \& Shumaker, 2015).

Tworzenie oferty edukacyjnej $\mathrm{w}$ bibliotece akademickiej jest procesem długotrwałym, podlegającym fluktuacjom związanym głównie z odbiorem, czyli stopniem zainteresowania ofertą ze strony użytkowników. Konieczne jest stałe monitorowanie i reagowanie na odbiór oferty edukacyjnej. Właściwym zaś podsumowaniem powinno być wykonanie post-testów, na podstawie których możliwe stanie się określenie bezpośrednich implikacji edukacji bibliotecznej na kompetencje użytkowników odzwierciedlone w ich wynikach edukacyjnych i naukowych (Oakleaf, 2008; Oakleaf, 2018; Samson, 2010). Jest to jednak zadanie trudne do realizacji ze względu m.in. na zbyt słabą współpracę bibliotek z kadrą naukową. Wskazane jest zatem zacieśnianie partnerstwa między bibliotekarzami a wykładowcami.

Istotną kwestią jest ustalenie, w jaki sposób kształtować ofertę edukacyjna, by zachęcić czytelników, a zwłaszcza studentów, do dobrowolnego korzystania ze szkoleń. Zwłaszcza, że z obserwacji bibliotekarzy oraz z literatury znane jest zjawisko wysokiej samooceny własnych umiejętności informacyjnych użytkowników oraz ich skuteczności i efektywności w zakresie korzystania z zasobów i usług bibliotecznych oraz posługiwania się technologią komputerową (Davidson, 2001; Kurbanoglu, 2003; Freeman, 2004; Gross \& Latham, 2007; Bronstein, 2014; Clark, 2017). W kontekście tworzenia i późniejszego promowania oferty szkoleniowej zjawisko to ma niebagatelne znaczenie. Chodzi bowiem o zachęcenie i przekonanie użytkowników bibliotek, głównie studentów, do tego, że konieczne jest rozwijanie wspomnianych kompetencji stosownie do wzrastających, wraz $\mathrm{z}$ dalszym zaawansowaniem $\mathrm{w}$ procesy edukacyjne i naukowe, potrzeb informacyjnych. Kolejną kwestia, którą należy uwzględniać przy planowaniu oferty dydaktycznej jest motywacja użytkowników do korzystania z niej.

Inna kwestia to konieczność silniejszego promowania oferty szkoleniowej bibliotek na uczelni. Doświadczenia BUW pokazują, że zamieszczanie informacji na stronie internetowej biblioteki, czy w mediach społecznościowych okazują się działaniami niewystarczającymi. Promowanie edukacji informacyjnej prowadzonej przez biblioteki należy kierować 
wielotorowo: do studentów, doktorantów, kadry naukowej oraz użytkowników zewnętrznych ze względu na ich zróżnicowane potrzeby informacyjne. Niezwykle istotny jest kontekst instytucjonalny, ponieważ, jak pisze J. Lau: „Pełny sukces wdrożenia programu edukacji informacyjnej uzależniony jest od zaangażowania na poziomie instytucjonalnym" (Lau, 2011, s. 31). Kwestia ta jest elementem kultury instytucjonalnej i znajduje odzwierciedlenie $\mathrm{w}$ dokumentach dotyczących misji lub strategii instytucji. Zainspirowana badaniami z obszaru brytyjskiej edukacji wyższej dotyczącej promowania zasad edukacji informacyjnej poprzez strony internetowe uniwersytetów w Wielkiej Brytanii (zbadano strony WWW 133 uczelni) (Ellis; Johnson; Rowley, 2017), autorka poddała, na cele niniejszego artykułu, ogólnemu przeglądowi zawartość stron internetowych 17 bibliotek głównych polskich uniwersytetów ${ }^{24}$. Zdecydowana większość z nich zamieszcza informacje na temat działalności dydaktycznej i szkoleniowej, tj. o dostępnych szkoleniach $\mathrm{w}$ formie online bądź prowadzonych na miejscu oraz ich zakresie tematycznym. Jedynie pięć $\mathrm{z}$ nich $\mathrm{w}$ tekstach dotyczących misji lub strategii biblioteki uwzględnia zapisy o kształceniu umiejętności informacyjno-wyszukiwawczych użytkowników. Brak innych zapisów dotyczących realizacji edukacji informacyjnej.

Obydwa badania ankietowe przeprowadzone przez autorkę okazały się komplementarne. Do najważniejszych wyników należy zaliczyć te, które wskazują na fakt dobrowolnego uczestniczenia w szkoleniach bibliotecznych, zainteresowanie studentów ofertą szkoleniową oraz wykazujące preferowaną formę i tematykę szkoleń. Konfrontacja tych rezultatów z rzeczywistym udziałem użytkowników w szkoleniach już oferowanych stanowi istotną wskazówkę, że konieczne jest podjęcie przez bibliotekarzy stosownych działań w celu promowania zarówno szkoleń, jak i samej idei edukacji bibliotecznej i informacyjnej na uczelni - zarówno wśród studentów, lecz w dużej mierze także pośród pracowników naukowych (Eva \& Shea, 2015). Należy rozważyć nie tylko zakres tematyczny (szkolenie uniwersalne, typu one-size nie jest $\mathrm{w}$ stanie zapewnić odpowiednich rezultatów) oraz efektywne formy szkoleń, poddać analizie zachowania i potrzeby informacyjne użytkowników, ale również spróbować wypracować model, standardy umiejętności informacyjnych włączone do ogólnych wymogów edukacyjnych na danej uczelni. Rozważyć można powołanie zespołu badawczego i dydaktycznego obejmującego bibliotekarzy oraz pracowników nauki, którego zadaniem będzie budowanie skutecznego programu edukacji prowadzonej w bibliotece oraz włączenie jej do programu studiów, jak również nawiązanie bliskiej współpracy między

\footnotetext{
${ }^{24}$ Lista uniwersytetów wg Wykazu uczelni publicznych nadzorowanych przez ministra właściwego ds. szkolnictwa wyższego: http://www.nauka.gov.pl/uczelnie-publiczne/wykaz-uczelnipublicznych-nadzorowanych-przez-ministra-wlasciwego-ds-szkolnictwa-wyzszego-publiczneuczelnie-akademickie.html.
} 
wykładowcami a bibliotekarzami (Smith, 2014; Lindstrom \& Shonrock, 2006). Przydatne mogłoby być powołanie koordynatorów ds. edukacji informacyjnej na poszczególnych wydziałach uczelni.

W kontekście dydaktycznej oferty biblioteki istotne jest również poznanie motywacji studentów do korzystania z niej, a więc zbadanie relacji motywacji do rozwijania własnych umiejętności informacyjnych do procesu uczenia się (Jacobson \& Xu, 2002; Nichols Hess, 2015). Tak zróżnicowane aspekty działalności dydaktycznej nakładają zatem na bibliotekarzy wymóg prowadzenia ciągłych badań w celu kształtowania najwyższej jakości usług bibliotecznych, w tym oferty edukacyjnej.

Niezwykle ważne jest także, by przy projektowaniu oferty edukacyjnej bibliotekarze otrzymywali wsparcie - ze strony kadry naukowej, by planowane szkolenia odpowiadały rzeczywistym potrzebom uczestników (studentów, doktorantów, pracowników naukowych) w konkretnych sytuacjach edukacyjnych. Chodzi także o wsparcie instytucjonalne umożliwiające rozwijanie kompetencji dydaktycznych bibliotekarzy (np. uczestnictwo w kursach, szkoleniach z zakresu pedagogiki, metod nauczania, tworzenia szkoleń online). Potrzebne jest tworzenie odpowiedniego klimatu wsparcia dla uczących bibliotekarzy, by tworzona przez nich oferta dydaktyczna była jak najlepiej oceniana zarówno w ankietach ewaluacyjnych, jak również przekładała się na efekty osiągane przez uczestników szkoleń. A jak wskazuje literatura, ocena efektywności szkoleń bibliotecznych staje się coraz częstszą praktyką (Ariew \& Lener, 2007; Dziak, 2013).

\section{BIBLIOGRAFIA}

ACRL (2015). Framework for Information Literacy for Higher Education [online]. The Association of College and Research Libraries; [dostęp: 10.03.2018]. Dostępny w WWW: $<$ https://alair.ala.org/bitstream/handle/11213/7668/ACRL\%20Information\%20Literacy\%20Competency\%20Standards\%20for\%20Higher\%20Education.pdf?sequence=1\&isAllowed=y>.

Anderson, Karen; May, Frances A. (2010). Does the method of instruction matter? An experimental Examination of information literacy instruction in the online, blended and face-to-face classrooms. The Journal of Academic Librarianship, vol. 36, pp. 495-500.

Andretta, Susie (2011). Evaluating information literacy educators' practices before and after the course facilitating information literacy education: from tutor to learner-centered. Health Information and Libraries Journal, vol. 28, pp.171-178.

Ariew, Susan; Lener, Edward (2007). Evaluating instruction: Developing a program that supports the teaching librarian. Research Strategies, vol. 20, pp. 506-515.

Badke, William (2010). Foundations of information literacy: learning from Paul Zurkowski [online]. Infolitland; [dostęp: 28.04.2018]. Dostępny w WWW: <https://www.researchgate.net/publication/293703989_Foundations_of_information_literacy_Learning_from_ paul_zurkowski>. 
Batorowska, Hanna (2015). Od edukacji informacyjnej ucznia do kultury informacyjnej człowieka dorosłego. W: Bibliotekarz 2.0. Nowoczesność na bazie tradycji. Pod red. S. Skórki i M. Rogoża. Kraków: Wydaw. Naukowe Uniwersytetu Pedagogicznego, s. 34-51.

Bond, Paul (2016). Addressing information literacy through student-centered learning. Education and Information, vol. 31, pp. 3-9.

Bronstein, Jenny (2014). The role of perceived self-efficacy in the information seeking behavior of library and information science students. The Journal of Academic Librarianship, vol. 40, pp. 101-106.

Brzezińska, Danuta (2008). Projekt reformy programowej. Próbowaliśmy to zmienić. Biblioteka w Szkole, z. 9, s. 3-6.

CILIP (2018). CILIP Definition of information literacy [online]. CILIP The Library and Information Association; [dostęp: 4.05.2018]. Dostępny w WWW:<https://infolit.org.uk/ ILdefinitionCILIP2018.pdf>.

Clark, Melissa (2017). Imposed-inquiry Information-seeking Self-efficacy and Performance of College Students: A Review of the Literature. The Journal of Academic Librarianship, vol. 43, pp. 417-422.

Cyfrowa przyszłość (2012). Cyfrowa przyszłość. Edukacja medialna i informacyjna w Polsce - raport otwarcia [online]. Fundacja Nowoczesna Polska; [dostęp: 20.09.2017]. Dostępny w WWW: <https://nowoczesnapolska.org.pl/wp-content/uploads/2012/01/Raport-Cyfrowa-Przysz \%C5\%820\%C5\%9B\%C4\%87-.pdf>.

Davidson, Jeanne R. (2001). Faculty and student attitudes toward credit courses for library skills. College \& Research Libraries, vol. 62, pp. 155-163.

Dąbrowska, Anna; Drzewiecki, Piotr; Jasiewicz Justyna; et al. (2012). Kształtowanie kompetencji medialnych i informacyjnych w podstawach programowych MEN [online].

Dziak, Joanna (2013). Ocena efektywności edukacji informacyjnej - przyczynek do metodologii [online]. BiE Elektroniczne Czasopismo Biblioteki Głównej Uniwersytetu Pedagogicznego w Krakowie, nr 3; [dostęp: 10.04.2018]. Dostępny w WWW: <cejsh.icm.edu.pl/ cejsh/element/bwmeta1.element.../c/BiE_nr_3_2013_A1_w2.pdf>.

Dziak, Joanna; Rozkosz, Ewa et al. (2013). Edukacja informacyjna w polskich bibliotekach akademickich - raport z badań. Bibliotheca Nostra, z. 1, nr 31, s. 26-41.

Edukacja informacyjna (2017). Z. W. [Zuza Wiorogórska] Edukacja informacyjna. W: Encyklopedia książki. Pod red. A. Żbikowskiej-Migoń i M. Skalskiej-Zlat. Wrocław: Wydaw. Uniwersytetu Wrocławskiego, t. 1, s. 595-599.

Ellis, Claire; Johnson, Frances; Rowley, Jennifer (2017). Promoting information literacy: perspectives from UK universities. Library Hi Tech, vol. 35, pp.53-70.

Eva, Nicole; Shea, Erin (2015). Marketing to faculty in an academic library. Reference \& User Services Quarterly, vol. 54, pp. 26-28.

Freeman, Christopher (2004). The relationship of undergraduate students' self-assessment of library skills to their opinion of library instruction: a self-reporting survey [online]. The Southeastern Librarian, vol. 52, pp. 39-46; [dostęp: 10.10.2017]. Dostępny w WWW: $<$ http://digitalcommons.kennesaw.edu/seln/vol52/iss3/8/>.

Fundacja Nowoczesna Polska; [dostęp: 20.09.2017]. Dostępny w WWW: <https://nowoczesnapolska.org.pl/wp-content/uploads/2012/01/Raport-Cyfrowa-Przysz\%C5\%82o$\% \mathrm{C} 5 \% 9 \mathrm{~B} \% \mathrm{C} 4 \% 87$-.pdf>.

Fundacja Orange (2013). Internet to cyfrowe podwórko młodych? Podstawowe wyniki badania "Kompetencje cyfrowe młodzieży w Polsce" [online]. Fundacja Orange; [dostęp: 20.10.2017]. 
Dostępny w WWW: <http://www.ceo.org.pl/sites/default/files/news-files/fci_kompetencje_cyfrowe_mlodziezy_w_polsce_podstawowe_wyniki_0.pdf $>$.

Greer, Katie; Nichols Hess, Amanda; Kraemer, Elizabeth W. (2016). The librarian leading the machine: a reassessment of library instruction methods. College \& Research Libraries, vol. 77, pp. 286-301.

Gross, Melissa; Latham, Don (2007). Attaining information literacy: an investigation of the relationship between skill level, self-estimates of skill, and library anxiety. Library \& Information Science Research, vol. 29, pp. 332-353.

Hoffman, Debra; LaBonte, Kristen (2012). Meeting information literacy outcomes: partnering with faculty to create effective information literacy assessment. Journal of Information Literacy, vol. 6, pp. 70-85.

Jacobson, Trudi; Xu, Lijuan (2002). Motivating students in credit-based information literacy. Libraries and the Academy, vol. 2, pp. 423-441.

Jerzyk-Wojtecka, Justyna (2015). Szkolenia z zakresu information literacy w Bibliotece Uniwersytetu Łódzkiego. Omówienie badań ewaluacyjnych. Acta Universitatis Lodziensis, Folia Librorum, z.1 (20), s. 69-85.

Kim, Sung Un; Shumaker, David (2015). Student, librarian and instructor perceptions of information literacy instruction and skills in a First Year Experience Program: a case study. Journal of Academic Librarianship, vol. 41, pp. 449-456.

Kurbanoglu, S. Serap (2003). Self-efficacy: a concept closely linked to information literacy and lifelong learning. Journal of Documentation, vol. 59, pp. 635-646.

Kurkowska, Ewa (2012). Edukacja informacyjna w bibliotekach a rozwój społeczeństwa wiedzy, Warszawa: Wydaw. SBP.

Lau, Jesus (2011). Kompetencje informacyjne w procesie uczenia się przez całe życie. Wytyczne [online]. SBP; [dostęp: 10.03.2018]. Dostępny w WWW: <https://www.ifla.org/ files/assets/information-literacy/publications/ifla-guidelines-pl.pdf $>$.

Lindstrom, Joyce; Shonrock, Diana (2006). Faculty-librarian collaboration to achieve integration of information literacy. Reference \& User Services Quarterly, vol. 46, pp. 18-23.

Mackey, Thomas; Jacobson, Trudi (2011). Reframing information literacy as a metaliteracy. College \& Research Libraries, vol. 71, pp. 62-78.

Marciniak, Aleksandra (2012). Szkolenie użytkowników w polskich bibliotekach uczelnianych. Historia i współczesność. Bibliotheca Nostra nr 1, s. 18-28.

Maybee, Clarence (2006). Undergraduate perceptions of information use: the basis for creating user-centered student information literacy instruction. The Journal of Academic Librarianship, vol. 32, pp. 79-85.

MedLibTrain (2010). MedLibTrain: zostań lepszym nauczycielem kompetencji informacyjnych: przewodnik nie tylko dla bibliotekarzy medycznych. Pod red. B. Niedźwiedzkiej i I. Hunskar, Kraków.

MENiS (2009a). Podstawa programowa kształcenia ogólnego dla szkót podstawowych. Załacznik nr 2 do rozporzadzenia Ministra Edukacji Narodowej z dnia 23 grudnia 2008 r. Dz. U. z dnia 15 stycznia 2009 r., Nr. 4, poz. 17 [online]. Ministerstwo Edukacji Narodowej i Sportu; [dostęp: 20.10.2017]. Dostępny w WWW: <http://prawo.sejm.gov.pl/isap.nsf/DocDetails.xsp?id=WDU20090040017>.

MENiS (2009b). Podstawa programowa kształcenia ogólnego dla gimnazjów i szkót ponadgimnazjalnych, których ukończenie umożliwia uzyskanie świadectwa dojrzałości po zdaniu egzaminu maturalnego. Załacznik nr 4 do rozporzadzenia Ministra Edukacji Narodowej z dnia 23 grudnia 2008 r. Dz. U. z dnia 15 stycznia 2009 r., Nr. 4, poz. 17 [online]. Ministerstwo Edukacji 
Narodowej i Sportu; [dostęp: 20.08.2017]. Dostępny w WWW: <http://prawo.sejm.gov. pl/isap.nsf/DocDetails.xsp?id=WDU20090040017>.

MEN (2017). Rozporzadzenie Ministra Edukacji Narodowej w sprawie podstawy programowej wychowania przedszkolnego oraz podstawy programowej kształcenia ogólnego dla szkoły podstawowej, w tym dla uczniów z niepetnosprawnościa intelektualna w stopniu umiarkowanym lub znacznym, kształcenia ogólnego dla branżowej szkoły I stopnia, kształcenia ogólnego dla szkoty specjalnej przysposabiającej do pracy oraz kształcenia ogólnego dla szkoły policealnej. Dz. U. z dnia 14 lutego 2017 r., poz. 356 [online]. Ministerstwo Edukacji Narodowej; [dostęp: 20.10.2017]. Dostępny w WWW: <http://www.dziennikustaw.gov.pl/DU/2017/356>.

Mery, Yvonne; Newby, Jill; Peng, Ke (2012). Why one-shot information literacy sessions are not the future of instruction: a case for online credit courses. College \& Research Libraries, vol. 73, pp. 366-377.

Nalewajska, Lilianna (2012). Szkolenia biblioteczne czy edukacja informacyjna? Bibliotekarz, z. 10, s. 7-11.

Nalewajska, Lilianna (2013). Dydaktyka w bibliotece akademickiej. Analiza potrzeb i możliwych zmian. Przeglad Biblioteczny, z. 1, s. 19-32.

Nichols Hess, Amanda (2015). Motivational design in information literacy instruction. Communications in Information Literacy, vol. 9, pp. 44-59.

Oakleaf, Megan (2008). Dangers and opportunities: a conceptual map of information literacy assessment approaches. portal: Libraries and the Academy, vol. 8, pp. 233-253.

Oakleaf, Megan; Kaske, Neal (2009). Guiding questions for assessing information literacy in higher education. portal: Libraries and the Academy, vol. 9, pp. 273-286.

Portmann, Chris; Roush, Adrienne (2004). Assessing the effects of library instruction. The Journal of Academic Librarianship, vol. 30, pp. 461-465.

Samson, Sue (2010). Information literacy learning outcomes and student success. The Journal of Academic Librarianship, vol. 36, pp. 202-210.

SCONUL (2011). The SCONUL Seven Pillars of Information Literacy: core model for higher education [online]. SCONUL Working Group on Information Literacy; [dostęp:10.03.2018]. Dostępny w WWW: <https://www.sconul.ac.uk/sites/default/files/documents/coremodel.pdf>.

Secker, Jane; Coonan, Emma (2013). Rethinking information literacy. A practical framework for supporting learning. London: facet publishing.

Silver, Susan L.; Nickel, Lisa T. (2007). Are online tutorials effective? A comparison of online and classroom library instruction methods. Research Strategies, vol. 20, pp. 389-396.

Smith, Anne-Marie (2014). Understanding the Relationship Between the Librarian and the Academic. New Review of Academic Librarianship, vol. 20, pp. 29-48.

Sprawozdanie BUW 2009 (2010). Sprawozdanie Biblioteki Uniwersyteckiej w Warszawie i bibliotek wydziatowych UW za rok 2009 [online]. Warszawa; [dostęp: 15.04.2018]. Dostępny w WWW: <http://www.buw.uw.edu.pl/wp-content/uploads/2016/10/sprawozdanie2009.pdf>.

Sprawozdanie BUW 2010 (2011). Sprawozdanie Biblioteki Uniwersyteckiej w Warszawie i bibliotek wydziałowych UW za rok 2010 [online]. Warszawa; [dostęp: 15.04.2018]. Dostępny w WWW: <http://www.buw.uw.edu.pl/wp-content/uploads/2016/10/spraw_buw_2010.pdf>.

Sprawozdanie BUW 2011 (2012). Sprawozdanie Biblioteki Uniwersyteckiej w Warszawie $i$ bibliotek wydziałowych UW za rok 2011 [online]. Warszawa; [dostęp: 15.04.2018]. Dostępny w WWW: <http://www.buw.uw.edu.pl/wp-content/uploads/2016/10/BUW_sprawozdanie_2011.pdf $>$. 
Sprawozdanie BUW 2012 (2013). Sprawozdanie Biblioteki Uniwersyteckiej w Warszawie i bibliotek wydziałowych UW za rok 2012 [online]. Warszawa: Wydaw. Uniwersytetu Warszawskiego; [dostęp: 15.04.2018]. Dostępny w WWW: <http://www.buw.uw.edu.pl/wp-content/uploads/2016/10/sprawozdanie2012.pdf>.

Sprawozdanie OUIN (2009). Sprawozdanie Oddziału Udostępniania i Informacji Naukowej za rok 2009 [niepublikowane].

Sprawozdanie OUIN (2010). Sprawozdanie Oddziału Udostęniania i Informacji Naukowej za rok 2010 [niepublikowane].

Sprawozdanie OUIN (2011). Sprawozdanie Oddziału Udostęniania i Informacji Naukowej za rok 2011 [niepublikowane].

Sprawozdanie OUIN (2012). Sprawozdanie Oddziału Udostępniania i Informacji Naukowej za rok 2012 [niepublikowane].

Sprawozdanie OUiS (2014). Sprawozdanie Oddziału Usług Informacyjnych i Szkoleń za 2014 rok [niepublikowane].

Sprawozdanie OUiS (2015). Sprawozdanie Oddziału Ustug Informacyjnych i Szkoleń za 2015 rok [niepublikowane].

Sprawozdanie OUiS (2016). Sprawozdanie Oddziału Usług Informacyjnych i Szkoleń za 2016 rok [niepublikowane].

Sprawozdanie OUiS (2017). Oddziat Ustug Informacyjnych i Szkoleń. Sprawozdanie za rok 2017 [niepublikowane].

Sprawozdanie roczne Rektora UW za rok 2009 (2010). Sprawozdanie roczne Rektora Uniwersytetu Warszawskiego za rok 2009 złożone na posiedzeniu Senatu Uniwersytetu Warszawskiego 16 czerwca 2010 r. [online]. Warszawa [dostęp: 10.04.2018]. Dostępny w WWW: <https:// www.uw.edu.pl/wp-content/uploads/2013/11/sprawozdanie-2009.pdf>.

Sprawozdanie Rektora UW z działalności uczelni w 2012 r. (2013). Sprawozdanie Rektora Uniwersytetu Warszawskiego z działalności uczelni w 2012 roku [online]. Warszawa: Wydawnictwa Uniwersytetu Warszawskiego [dostęp: 10.04.2018]. Dostępny w WWW: <https://www. uw.edu.pl/wp-content/uploads/2013/11/sprawozdanie-2012.pdf>.

Sühl-Strohmenger, Wilfried (2012). Teaching library: Förderung von Informationskompetenz durch Hochschulbibliotheken. Berlin: DeGruyter Saur.

Walsh, John (2008). The Effects of Library Orientations on Student Usage of the Library. Library Hi Tech News, vol. 1, pp. 27-29.

Wiorogórska, Zuzanna (2013a). Edukacja informacyjna stałym elementem programu studiów? W: Biblioteka w komórce? Przyszłość usług bibliotecznych. Materiały konferencyjne pod red. M. Wrocławskiej i J. Jerzyk-Wojteckiej. Łódź: Wydaw. Uniwersytetu Łódzkiego, s. 179-188.

Wiorogórska, Zuzanna (2013b). Shaping information literacy for enhancing the use of scientific journals. Comparative study on academic users' behaviour [rozprawa doktorska] [abstract online]. Uniwersytet Warszawski, Wydział Historyczny; [dostęp: 20.05.2017]. Dostępny w WWW: <https://depotuw.ceon.pl/handle/item/386>.

Wiorogórska, Zuzanna (2014). Doktoranci - mistrzowie czy zwykli studenci? Kompetencje informacyjne niezbędne studentom trzeciego stopnia. W: Czas przemian - czas wyzwań. Rola bibliotek $i$ ośrodków informacji w procesie kształtowania kompetencji wspótczesnego człowieka. Pod red. J. Jasiewicz i E. Zybert. Warszawa: Wydaw. SBP, s. 354-368.

Artykut w wersji poprawionej wptynąt do Redakcji 23 maja 2018 r. 


\section{PROCESS OF CREATING AN EDUCATIONAL OFFER OF AN ACADEMIC LIBRARY - CASE STUDY OF THE UNIVERSITY OF WARSAW LIBRARY}

KEYWORDS: Information literacy. Library pedagogy. Academic library. Library training. Information needs. Information users. Information behavior. University of Warsaw Library.

ABSTRACT: Thesis/Objective - The aim of the article is to present a process of creating an educational offer in an academic library. The description of the parts of this process, applied diagnostic tests, their results and methods of their use to create an educational offer can be used by other academic libraries as an aid in planning and subsequent monitoring and promotion of educational activities. Research methods - The author used the description of the stages of a several-year-long process of building a training offer and the analysis of the applied methodological solutions (forms of training) in the years 2012-2017. The strengths and weaknesses of the resulting offer were analyzed. In the case of the user opinion survey, the method of the diagnostic survey was chosen. Results - The process of creating an educational offer should be preceded by a broad diagnosis of the training offer provided by the university library system. It is necessary to learn about the opinions of the recipients of the training offer - students expressed great interest in the training, with more preference for the voluntary participation. The results of diagnostic tests indicated two equally preferred forms of training: the onsite one in the library providing an opportunity to interact with the teacher and the online one in the form of short tutorials or movies. Conclusions - Creating an educational offer in academic libraries should be preceded by diagnostic tests of the users' information needs and skills in order to create an offer most suitable for the participants. It is a long-lasting process, subject to fluctuations related to the reception of the offer. It is also indispensable to promote training at the university among diverse groups of recipients (students, PhD students, lecturers). 